\title{
3R: Suatu Alternatif Pengolahan Sampah Rumah Tangga
}

\author{
Ria Noviana Agus', Rina Oktaviyanthi' ${ }^{2}$, Usep Sholahudin ${ }^{3}$ \\ 1,2,3 Pendidikan Matematika, Universitas Serang Raya \\ Email: ria_an99@yahoo.co.id; rinaokta1210@yahoo.com; sholahudin.usep@mail.com
}

\begin{abstract}
Abstrak
Kegiatan pengabdian ini difokuskan kepada sosialisasi pengolahan sampah rumah tangga dan pelatihan pembuatan kerajinan tangan dari koran bekas. Untuk mencapai tujuan digunakan metode community based participatory action dengan tahapan kegiatan terdiri atas perencanaan, pelaksanaan, dan evaluasi. Ada 21 peserta ibu-ibu PKK dan remaja putri desa petir, kecamatan petir, kabupaen serang. Persentase pemahaman peserta rata-rata $80 \%$ pada kegiatan community based participatory action tentang sosialisasi pengolahan sampah rumah tangga dan pelatihan pembuatak kerajinan tangan dari koran bekas, jadi. Rata-rata pemahaman tersebut memberikan respon yang baik, oleh karena itu kegiatan pengabdian ini diharapkan dapat menyadarkan masyarakat desa petir untuk dapat bijaksana mengolah sampah dan dapat membuat kerajinan tangan dari sampah yang masih bisa dipakai dan di daur ulang yang dapat bernilai ekonomis.
\end{abstract}

Kata Kunci: community based participatory action; pengolahan sampah rumah tangga, kerajinan tangan dari koran bekas

\begin{abstract}
This service activity is focused on socializing the processing of household waste and training in making handicrafts from used newspapers. To achieve the objectives, the method used is community based participatory action with the stages of activities consisting of planning, implementation, and evaluation. There were 21 participants from the women and girls in the village of Petir. The percentage of participants' understanding averaged $80 \%$ in community-based participatory action activities on the socialization of processing household waste and training in making handicrafts from used newspapers. The average understanding gives a good response, therefore this service activity is expected to be able to make people aware of the lightning village to be able to wisely process waste and can make handicrafts from garbage that can still be used and recycled which can have economic value.
\end{abstract}

Keywords: community based participatory action; processing household waste, handicrafts from used newspapers

\section{PENDAHULUAN}

Istilah sampah yang ada didalam pikiran kita pasti merupakan setumpuk kotoran baik berupa kertas, plastik, dan barang lainnya yang menimbulkan bau sangat menyengat atau bau tidak enak. Menurut Chandra pengertian sampah dalam WHO adalah sesuatu yang tidak dipakai, tidak disenangi, tidak digunakan atau sesuatu yang berasal dari kegiatan seseorang jadi tidak terjadi dengan sendirinya (Fadhilah arief, 2011). Persoalan sampah sudah sangat meresahkan karena semakin hari semakin banyk, ini sesuai pernyataan dari Kementerian Lingkungan Hidup dan kehutanan
(KLHK). Menurut data Jambeck 2015 yang dikutip Antara (2016), Indonesa berada di peringkat kedua dunia setelah Cina penghasil sampah plastik ke laut, Sampah yang dihasilkan Cina mencapai 262,9 juta ton sedaangkan indonesia yang mencapai 187, juta ton. Tentu merupakan jumlah yang sangat banyak dan pasti merusak ekosistem yang ada di laut.

Sampah akan menumpuk terus menerus apabila tidak dikelola dengan baik. Apalagi sampah yang menumpuk lama kelamaan akan menjadi padat dan berserakan, sehingga dapat mengganggu suasana. Lingkungan menjadi kumuhdan kotor. Sampah menjadi penyebab banjir apabila musim hujan tiba 
dan sampah akan mudah terbakar di saat musim kemarau yang menyebabkan pencemaran lingkungan dan mengganggu pemukiman (Tobing SL imran. 2005). Setiap saat masyarakat menghasilkan sampah baik organik, anorganik maupun bahan beracun atau berbahaya, tetapi tidak banyak yang menyadarinya. Salah satu sumber sampah yaitu berasal dari pemukiman warga masyarakat atau yang biasa disebut sampah rumah tangga. Untuk itu dilakukan sosialisasi tentang cara mengolah sampah rumah tangga dengan cara memilah sampah. Memilah sampah merupakan sebagian kecil dari serangkaian kegiatan dari Bank Sampah. Apabila masyarakat sudah sadar dan terbiasa memilah sampah antara sampah plastik, kertas dan organik yang bisa di daur ulang, maka kedepannya diharapkan dapat mendirikan suatu bank sampah.

UU RI No 18 tentang pengelolaan sampah disebutkan bahwa permasalahan sampah itu ada banyak sebab, maka dari itu pengelolaan sampah harus dilakukan secara menyeluruh dan pembaruan dengan menginovasi cara pengolahannya dimulai dari hulu ke hilir atau cara mengolah sampah harus di mulai dari sumbernya. Mengolah sampah dengan konsep 3R yaitu reuse(menggunakan kembali), reduce (mengurangi), recycle (mendur ulang). Merupakan cara untuk mengolah sampah dari hulu dalam artian sampah rumah tangga. Mengaplikasikan konsep 3R sebetulnya mudah tapi diperlukan kesadaran masyarakat itu sendiri (Puspitawati, 2012). Maka dari itu diperlukan adanya sosialisasi tentang bahaya sampah terhadap kesehatan dan lingkungan.

Menurut Sumanto (2015) Kerajinan tangan adalah kegiatan yang berhubungan dengan menciptakan suatu barang atau produk yang dihasilkan dari keterampilan tangan atau kegiatan yang berhubungan dengan menghasilkan suatu barang. Kerajinan tangan yang bernilai ekonomis adalah Kerajinan yang dibuat berupa barang atau produk yang mempunyai kuantitas terbaik dengan pemilihan bahan seminimal mungkin. Apabila masyarakat terbiasa mengolah sampah dengan memilah mana yang masih bisa di pakai dan di daur ulang dan jumlahnya cukup banyak, masyarakat tidak perlu khawatir misalkan ada sampah plastik dibuat tas, untuk bahan dasar koran dapat dibuat keranjang. Tentu saja barang-barang kerajinan tangan yang sudah jadi dapat dijual, dengan harapan dapat meningkatkn taraf ekonomi keluarga.

Dengan adanya sosialisasi ini diharapkan masyarakat desa petir mengerti tentang cara mengolah sampah rumah tangga yaitu tujuan akhir pembuangan sampah itu tidak hanya dibakar atau dibuang begitu saja ke tempat pembuangan sampah pada akhirnya ketempat pembuangan akhir. Akan tetapi sampah itu sebetulnya bisa dipilah pilah dengan konsep 3R yaitu reuse(menggunakan kembali), reduce (mengurangi), recycle (mendur ulang). Dari 3R bisa dibuat sebuah produk kerajinan misalkan dari plastik atau koran bekas sehingga dapat memberikan manfaat secara ekonomi bagi masyarakat dan aman bagi lingkungan.

\section{METODE PELAKSANAAN}

Metode yang digunakan untuk mencapai tujuan kegiatan pengabdian adalah community based participatory action yang tahapannya terdiri atas perencanaan, pelaksanaan dan evaluasi yang diterapkan pada ibu-ibu PKK dan remaja putri desa petir. Community based participatory action adalah bagian dari Participatory action research yaitu metode yang melibatkan peneliti dan peserta untuk bekerjasama memahami situas yang bermasalah dan mengubahnya menjadi berubah lebih baik (Gills \& Jackson, 2002;Macdonald,2012). Metode PAR menurut Mubuuke(2013) Memiliki potensi untuk menghasilkan inovasi yang mudah diterima dan berkelanjutan karena semua terlibat antara pemangku kepentingan.

\section{HASIL DAN PEMBAHASAN}

Kegiatan pengabdian sosialisasi untuk memahamkan cara pengolahan sampah rumah tangga dan pelatihan pembuatan kerajinan tangan dari koran bekas dengan metode community based participatory action yang terdiri atas perencanaan, menghasilkan pemahaman sebesar $80 \%$, merupakan respon dan nilai yang baik. Dalam kegiatan mengolah sampah dengan konsep 3R sampah rumah tangga dan pembuatan kerajinan tangan dari koran bekas mempunyai presentase terbesar karena 
ibu-ibu pkk dan remaja putri mengamati dan mempraktekan langsung kegiatan tersebut di bawah bimbingan fasilitator.

Adapun langkah-langkah pengabdian dengan metode community based participatory action yaitu:

\section{Perencanaan}

a. Tim pengabdian dari universitas serang raya yang disebut sebagai fasilitator.

b. Observasi wilayah desa petir, menganalisis permasalahan yang ada di desa petir dan menyusun strategi untuk dapat mengurangi permasalahan tersebut

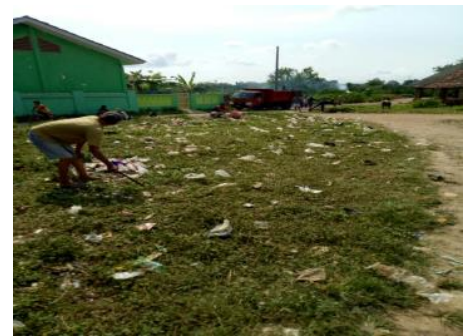

Gambar 1. Lingkungan Desa Petir

2. Pelaksanaan

a. Fasilitator berkoordinasi dengan kepala desa, Rt 01 dan Rw 01 desa petir tentang agenda untuk mengadaakan sosialisai tentang pengolahan sampah rumah tangga dan pelatihan kerajinan tangan dari koran bekas. Dengan peserta ibu-ibu PKK dan remaja putri karena merupakan kelompok yang aktif dalam kegiatan bermayarakat

b. Fasilitator bersama bapak Rt mengundang ibu-ibu PKK dan remaja putri sebanyak 21 orang untuk mengikuti kegiatan tersebut.

c. Fasilitator mengadakan sosialisi tentang pengolahan sampah rumah tangga dengan konsep 3R. Pada awalnya fasilitator menjelaskan cara memilah sampah antara plastik, kertas, dan organik yang masih dapat dipakai. Karena ketiga bahan yang masih dapat dipakai tersebut masing-masing dapat diolah kembali, misalkan untuk plastik dapat dibuat tas, untuk organik dapat dijadikan kompos, dan untuk kertas terutama koran bekas dapat dibuat keranjang dll.

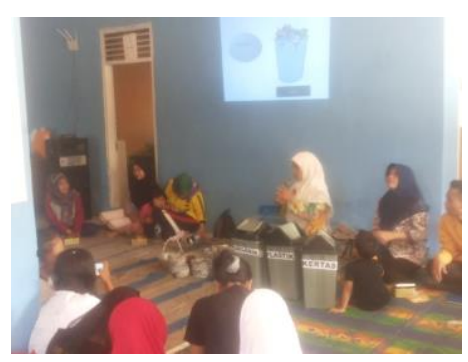

Gambar 2. Kegiatan Sosialisasi Pengolahan sampah rumah tangga dengan konsep 3R

d. Fasilitator mengajarkan cara membuat kerajinan tangan dari koran bekas yang dapat dijadikan bermacam macam keranjang setelah kegiatan sosialisasi selesai. Dari 21 peserta ibu-ibu PKK dan remaja putri dibuat 5 kelompok masing-masing 4 anggota, dan langsung di dampingi oleh fasilitator.

Adapun tahapan membuat kerajinan tangan dari koran bekas adalah :

Alat dan Bahan antara lain: Koran,Lem Kertas, Gunting Kecil, Kuas Kecil, Lidi, Cat/ Pewarna Kayu, Karton Bulat 2.

Cara Membuat :

- Gunting koran menjadi empat bagian.

- Gulung koran dengan bantuan lidi menjadi gulungan kecil

- Koran ditempelkan disekitaran lingkaran kardus

- Tambahkan satu gulungan koran untuk menganyam, gunakan toples sebagai alat bantu

- Mulailah menganyam dari gulungan yang diselipkan dengan cara selang seling

- Sambung gulungan jika mulai habis

- Jika tinggi anyaman dirasa sudah cukup, rapikan anyaman dengan menyelipkan sisa gulungan koran

- Cat anyaman dengan menggunakan Cat/Pewarna kayu.

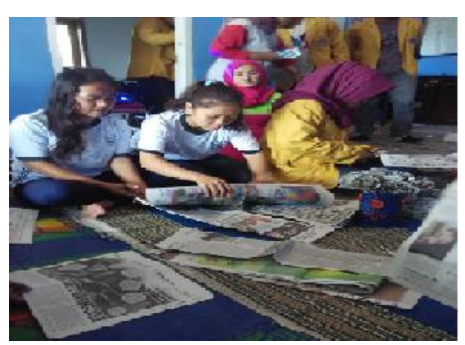

Gambar 3. Pelatihan Pembuatan

Kerajinan Tangan dari Koran Bekas 
e. Kegiatan pelatihan kerajinan tangan dari koran bekas Menghasilkan beberapa produk antara lain tempat permen, keranjang dan vas bunga dari koran.

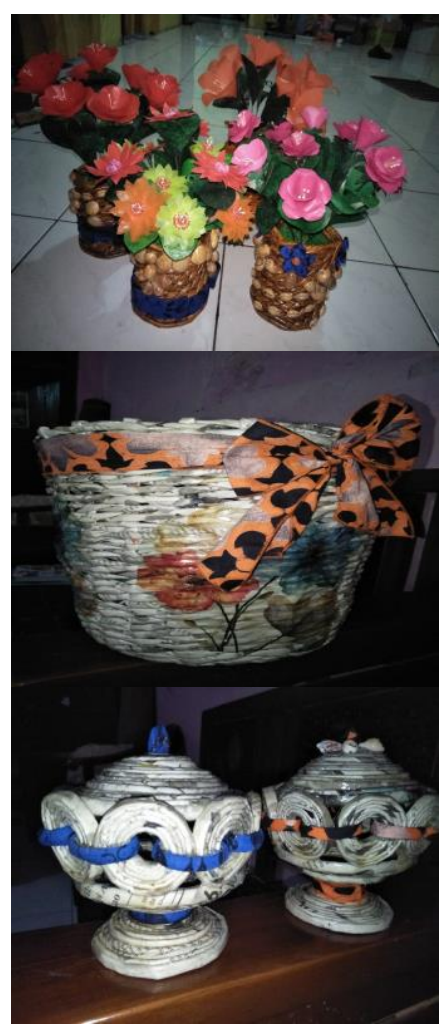

Gambar 4. Hasil PelatihanPembuatan Kerajinan Tangan dari Koran Bekas

\section{Evaluasi}

Kegiatan pengabdian di akhiri dengan evaluasi melalui pengisian angket untuk mengetahui berapa persen pemahaman peserta sosialisasi kegiatan. Pada tabel 1 memperlihatkan data, untuk rata-rata pemahaman peserta dalam kegiatan sosialisasi pengelolaan sampah rumah tangga dan pembuatan kerajinan tangan dari koran bekas adalah $80 \%$. Nilai tersebut sangat baik dan memberikan sinyal positif bahwa kegiatan pengabdian dapat menyadarkan masyarakat desa petir untuk dapat bijaksana mengolah sampah dan dapat membuat kerajinan tangan dengan harapan dapat menjadikan nilai ekonomis.

Tabel 1. Persentase Hasil Angket Pemahaman

\begin{tabular}{|c|c|c|}
\hline Aspek yang & \multicolumn{2}{|c|}{ Pilihan Jawaban } \\
\hline Diamati & $Y a$ & Tidak \\
\hline $\begin{array}{lr}\text { Saya } & \text { mengerti } \\
\text { dengan } & \text { penjelasan } \\
\text { fasilitator } & \text { tentang } \\
\text { cara } & \text { mengolah }\end{array}$ & $90 \%$ & $10 \%$ \\
\hline
\end{tabular}

sampah dengan

konsep 3R sampah rumah tangga.

Pemahaman saya terhadap cara pembuatan kerajinan tangan dari koran $90 \% \quad 10 \%$ bekas tidak ada kesulitan

Binaan dan bimbingan fasilitator dalam pengelolaan sampah membuat saya semakin sadar $85 \% \quad 15 \%$ dalam menjaga lingkungan tempat tinggal.

Binaan dan bimbingan fasilitator dalam pembuatan kerajinan tangan dari koran memotivasi $65 \% \quad 35 \%$ saya untuk membuka peluang bisnis.

Saya melihat bahwa tahapan kegiatan yang ditunjukkan $65 \% \quad 35 \%$ fasilitator memiliki kesulitan bertahap.

Ada antusiasme yang tinggi untuk menyebarkan

informasi tentang sosialisasi

pengolahan sampah $85 \%$ $15 \%$

\section{UCAPAN TERIMA KASIH}

Ucapan terimakasih kepada Universitas Serang Raya, Kepala desa, bapak RT dan Bapak Rw desa 
petir dan segenap warga atas partisipasinya sehingga kegiatan ini dapat berjalan dengan baik.

\section{KESIMPULAN DAN SARAN}

Apabila dilihat dari prosentase hasil pemahaman kegiatan sebesar $80 \%$ yang berarti mendapat respon yang baik, maka kegiatan pengabdian ini diharapkan dapat menyadarkan masyarakat desa petir untuk dapat bijaksana mengolah sampah dan dapat membuat kerajinan tangan dari sampah yang masih bisa dipakai dan di daur ulang sehingga dapat bernilai ekonomis.

\section{DAFTAR REFERENSI}

Antara,(2016). Indonesia penyumbang sampah plastik terbesar ke dua dunia.http://www.cnnindonesia.com/gayahidup/20160222182308-277-

112685/indonesia-penyumbang-sampahplastik-terbesar-ke-dua-dunia/.

Fadhilah,A. Sugianto, H dan Hadi,.K.(2011). Kajian pegelolaan Sampah Kampus. Modul Vol 11 No. 2 agustus 2011 ISSN: 0853-2877.

Macdonald Cathy, (2014) . Understanding Participatory Action Research: A Qualitative Research Metodology Option. Canandian Journal Of Actions Research, Vol. 13, Issue 2, 2014, page 34.

Mubuuke, (2013). Participatory Action Research: The Ky To Sucsesful Implementation Of Innovations Inhealth Professions Education, AJHEP (African Journal Of Health Profession Education, Vol. 5 No. 1, 2013.

Puspitawati, Y. dan Rahdriawan, M. (2012). Kajian Pengelolaan Sampah Berbasis Masyarakat dengan Konsep 3R (Reduce, Reuse, Recycle) di Kelurahan Larangan Kota Cirebon. Jurnal Pembangunan Wilayah dan Kota. Vol 8(4):349-359 Desember 2012.

Sumanto, Gipayana, Rumidjan.( 2015). Kerajinan Tangan Di Blitar Sebagai Sumber Belajar Seni Budaya Dan Prakarya (Sbdp) Sekolah Dasar. Sekolah Dasar, Tahun 24 Nomor 2, November 2015, Hlm 111-123.

Suryani,S. (2014). Peran Bank Sampah dalam Efektivitas Pengelolaan Sampah (Studi Kasus Bank Sampah Malang). Aspirasi vol 5 no 1 Juni.

Tobing, SL. dan Imran. (2005). Dampak Sampah Terhadap Kesehatan Lingkungan dan
Manusia. Makalah pada Lokakarya "Aspek Lingkungan dan Legalitas Pembuangan Sampah serta Sosialisasi Pemanfaatan Sampah Organik sebagai Bahan Baku Pembuatan Kompos Kerjasama Univ Nasional dan Dikmenti DKI Jakarta. 